\title{
IMPACT OF NATURAL FERTILIZATION USING PRP FIX ON SOME SOIL FERTILITY INDICATORS
}

\author{
Ewa Możdżer', Justyna Chudecka' \\ 1 Department of Soil Science, Grassland Management and Environmental Chemistry, Faculty of Environmental \\ Management and Agriculture, Western Pomeranian University of Technology in Szczecin, Słowackiego 17 Str., \\ 71-434 Szczecin, Poland, e-mail: ewa.mozdzer@zut.edu.pl
}

Received: 2017.04.19

Accepted: 2017.05.31

Published: 2017.07.01

\begin{abstract}
The field experiment was carried out at The Experimental Station of Plant Varieties Protection in Szczecin Dąbie. The experiment aimed at evaluating the influence of slurry with and without increasing doses of PRP FIX preparation on some soil fertility indicators after test plants harvest. The contents of determined macronutrients in the soil were higher in objects where slurry was applied with addition of $8 \mathrm{~kg}$ or $12 \mathrm{~kg}$ of PRP FIX per $1 \mathrm{~m}^{3}$ as compared to those with exclusively mineral fertilization or slurry. The soil after test plants harvest contained more N, Corg., P, K, Mg, Ca, S, and available forms of $\mathrm{P}, \mathrm{K}, \mathrm{Mg}$ and $\mathrm{SO}_{3}$, in relation to levels before experiment establishment. In general, more soil fertility indicators were recorded in objects treated with the slurry along with PRP FIX preparation and additional PK nutrition (series II) as compared to series I. Differences in macronutrients in the soil due to the fertilization system applied were diverse, however, they not always were significant.
\end{abstract}

Keywords: soil, liquid manure, PRP Fix, total contents macroelement, absorbable forms $\mathrm{P}, \mathrm{K}, \mathrm{Mg}$

\section{INTRODUCTION}

The existing environmental legislation has imposed the obligation on producers to manage natural fertilizers, including manure and slurry. It has been shown to date that swine manure is characterized by natural acidity, small amount of dry matter, and significantly higher nitrogen and potassium contents in relation to phosphorus [Filipek 2006]. It was found that slurry introduced into the light soils at optimal doses contributed to the increase in organic matter, organic carbon, macronutrient contents and enzymatic activity [Renell et al. 2007, Nartclift et al. 2002, TrasarCepedo et al. 2008, Yang 2008]. Incorrect storage and use of slurry in spring, summer and autumn can lead to contamination of the environment (soil, atmosphere and water) and contribute to a decrease in the quality of crop yields. In addition, intensive and long-term fertilization of soils using slurry may also adversely affect the physical and phyto-sanitary properties, cause the groundwater salinity and negatively impact the environment [Mazur and Gorlach 2001]. Slurry is a fertilizer that, when stored and used, emits unpleasant odors [Blanes-Vidal et al. 2008, Hofmann and et. 2010]. The French company Procedes Roland Pigeon produces PRP FIX that, among others, reduces the amount of ammonia and other odorants by about $30 \%$, increases the fertilization value of natural fertilizers and stimulates the growth of microorganisms. It is a mixture of a dozen or so natural components, specially selected to stimulate specific directions of organic matter fermentation occurring in feces, litter, or slurry. It has a beneficial effect on slurry as it improves its consistency and reduces its odor. PRP FIX works by stimulating the oxygen microorganisms present in a given environment. By applying this product, undesirable microorganisms are not introduced. As a result, organic matter is transformed into humus. This protects the organic components from 
mineralization and degradation. PRP FIX stimulates the conversion of manure and slurry into fertilizer that is characterized by better nutrient assimilation, allowing for faster and more efficient use by soil and plants.

\section{MATERIAL AND RESEARCH METHODS}

The field vegetation experiment was conducted in 2011-2013 at The Experimental Station of Plant Varieties Protection in Szczecin Dąbie and aimed at evaluating the impact of slurry with and without addition of increasing PRP FIX preparation doses on some soil fertility indicators.

The soil under the experiment is qualified as shallow mineral one on loose sand of weak rye complex and quality classes from IV to VI. Prior to the experiment, three average soil samples were collected from the arable layer $(0-20 \mathrm{~cm})$. Chemical analyses revealed that the soil was characterized by slightly acidic reaction $\left(\mathrm{pH}_{\mathrm{KCl}}\right.$ 5.95), while total nitrogen, phosphorus, and potassium contents amounted respectively to 0.86 , 1.55 , and $2.70 \mathrm{~g} \cdot \mathrm{kg}^{-1} \mathrm{~d} . \mathrm{m}$. The total level of macronutrients for this type of soil was average. Abundance in plant-available forms of phosphorus (55.3 $\mathrm{mg} \cdot \mathrm{kg}^{-1} \mathrm{~d} . \mathrm{m}$.), magnesium (49.3 $\mathrm{mg} \cdot \mathrm{kg}^{-1}$ d.m.), and sulfur (11.0 mg $\left.\mathrm{kg}^{-1} \mathrm{~d} . \mathrm{m}\right)$ was also average, whereas that of potassium $\left(132 \mathrm{mg} \cdot \mathrm{kg}^{-1}\right.$ d.m.) high. The organic carbon content in the soil was low $\left(8.80 \mathrm{~g} \cdot \mathrm{kg}^{-1} \mathrm{~d} . \mathrm{m}\right.$.), while C:N ratio was 10.2:1, which was moderate for this type of soils. The two-factor field experiment was set up in autumn 2011 according to the pattern presented in Table 1. Quantity of a slurry dose introduced into the soil during the I and II series of tests was established based on the nitrogen content that corresponded to $100 \mathrm{~kg} \mathrm{~N} \cdot \mathrm{ha}^{-1}$.

After slurry treatment, mineral fertilization was applied according to the experimental procedure. In spring 2012 and 2013 for series I and
II on all fertilization objects, the top dressing was used in a form of urea $(46 \% \mathrm{~N})$ at rates of $45 \mathrm{~kg}$ $\mathrm{N} \cdot \mathrm{ha}^{-1}$ under winter rapeseed and $30 \mathrm{~kg} \mathrm{~N} \cdot \mathrm{ha}^{-1}$ under spring wheat.

An additional mineral nutrition was established in the II series of experiment based on phosphorus and potassium contents in the slurry, which was $90 \mathrm{~kg} \mathrm{P}_{2} \mathrm{O}_{5} \cdot \mathrm{ha}^{-1}$ as granulated triple superphosphate with $46 \% \mathrm{P}_{2} \mathrm{O}_{5}$ corresponding to $0.65 \mathrm{~kg}$ dose per plot as well as $100 \mathrm{~kg} \mathrm{~K} \mathrm{O}_{2} \mathrm{O} \cdot \mathrm{ha}^{-1}$ in a form of potassium salt $(\mathrm{KCl})$ containing $60 \%$ $\mathrm{K}_{2} \mathrm{O}$, which corresponded to $0.55 \mathrm{~kg} \mathrm{KCl}$ rate. Winter triticale, winter rapeseed, spring wheat, and potato were the test plant species.

The soil samples were collected after test plants harvest. Soil material was subject to determinations of macronutrients in average samples from four replicates for every fertilization object. Average soil samples were subject to chemical analyses in three replicates. Nitrogen, carbon, and sulfur contents were determined using CNS elemental analyzer (Coestech), the available forms of phosphorus and potassium - EgnerRiehm method, available magnesium - according to PN-R-04024, total phosphorus - according to PN-98/C-04537-14, total potassium and calcium - flame photometry, total magnesium - AAS technique according to PN-EN ISO 11212 and PN-EN ISO 11212-4 using spectrometer (Perkin Elmer AAS 300). The stock solution for determinations of total contents of macronutrients was prepared by means of the soil wet digestion in the mixture of nitric (V) with perchloric (VII) acids at 1:1 ratio according to PN-ISO 11466 and PN-ISO 11047 , the $\mathrm{pH}$ value - potentiometry in $1 \mathrm{~mol} \cdot \mathrm{dm}^{-3}$ $\mathrm{KCl}$ according to $\mathrm{PN}-75 / \mathrm{C}-04540 / 05 / 01$.

Results of macronutrients contents in the test soil were subject to statistical processing. The two-factor variance analysis for split-block pattern was used. The confidence intervals were determined for $p=0.05$ applying Tukey test.

Table. 1. Testing diagram

\begin{tabular}{|l|c|c|}
\hline \multicolumn{1}{|c|}{ Fertilisation objects } & Series I & Series II \\
\cline { 2 - 3 } & without additional mineral fertilisation & with additional PK fertilisation \\
\hline Mineral fertilisers corresponding to a slurry dose & + & + \\
\hline Slurry without PRP Fix & + & + \\
\hline Slurry $+4 \mathrm{~kg}$ of PRP Fix & + & + \\
\hline Slurry $+8 \mathrm{~kg}$ of PRP Fix & + & + \\
\hline Slurry $+12 \mathrm{~kg}$ of PRP Fix & + & + \\
\hline
\end{tabular}




\section{RESULTS AND DISCUSSION}

Slurry used for the experiments contained $2.46 \%$ of dry matter, $3.23 \mathrm{~g} \cdot \mathrm{m}^{3}$ of nitrogen and $3.52 \mathrm{~g} \cdot \mathrm{m}^{3}$ of potassium. According to Filipek [2006], these values are lower than average one. While total phosphorus $\left(1.75 \mathrm{~g} \cdot \mathrm{m}^{3}\right)$, calcium $(2.42$ $\left.\mathrm{g} \cdot \mathrm{m}^{3}\right)$, and magnesium contents $\left(0.76 \mathrm{~g} \cdot \mathrm{m}^{3}\right)$ indicated average levels. Microelements determined in the slurry, including some heavy metals, did not show excessive concentrations. Slurry used in the experiment did not threaten the soil and aqueous environments due to pollution.

Data on chemical properties of PRP FIX preparation indicate that calcium is its main component, then magnesium and sodium (Table 2). Although it also contains potassium, sulfur, and nitrogen, yet at small amounts. The tested preparation is produced using natural fossils, therefore, it contains microelements and heavy metals, the concentrations of which are low enough not to pose any harm for soils.

Value of $\mathrm{pH}_{\mathrm{KCl}}$, carbon, nitrogen, phosphorus, potassium, magnesium, calcium, and sulfur as well as plant-available forms of phosphorus, potassium, magnesium, and sulfate contents in the soil after experiment completion, were higher than before the establishment in 2011.

Value of $\mathrm{pH}_{\mathrm{KCl}}$ in the soil after experiments was higher in series I without additional mineral nutrition as compared to complementary use of phosphorus and potassium fertilizers (series II). Additional phosphorus-potassium nutrition (PK) decreased the value of $\mathrm{pH}_{\mathrm{KCl}}$ in soil, which was associated with acidifying influence of these fertilizers [Krzywy 2005]. Lower $\mathrm{pH}_{\mathrm{KCl}}$ values were recorded in objects with slurry treated with $12 \mathrm{~kg}$ PRP FIX. These values were significantly higher comparing to objects without fertilization, with additional PK nutrition, and with slurry without PRP FIX preparation treatment (Table 3).

Analysis of the impact of slurry with PRP FIX at the amount of $8 \mathrm{~kg}$ per $1 \mathrm{~m}^{3}$ both for series with and without complementary PK nutrition (series I and II) revealed an increase in nitrogen content in the soil after spring wheat and potato harvest between objects 5 and 100 respectively by $9.37 \%$ and $5.80 \%$ (Table 4 ). The largest increase in the

Table 2. Content of dry matter and macronutrients in the preparation PRP Fix

\begin{tabular}{|c|c|c|c|c|c|}
\hline \multirow{2}{*}{ d.m. } & $\mathrm{CaO}$ & $\mathrm{MgO}$ & $\mathrm{K}_{2} \mathrm{O}$ & $\mathrm{S}^{-\mathrm{SO}_{3}}$ & $\mathrm{~N}$ \\
\cline { 2 - 6 } & \multicolumn{5}{|c|}{ Total content in $\mathrm{g} \cdot \mathrm{kg}^{-1} \mathrm{~d} . \mathrm{m}}$. \\
\hline 995 & 375 & 44.0 & 5.0 & 7.0 & 1.0 \\
\hline
\end{tabular}

Table 3. The $\mathrm{pH}$ value of the soil after the end of the experiment

\begin{tabular}{|c|c|c|c|}
\hline \multirow{2}{*}{ Exsperiment series } & \multirow{2}{*}{ Fertilisation objects } & \multicolumn{2}{|c|}{$\mathrm{pH}_{\mathrm{KCl}}$} \\
\hline & & wheat & potato \\
\hline \multicolumn{2}{|l|}{ The output value } & \multicolumn{2}{|c|}{5.95} \\
\hline \multirow{6}{*}{$\begin{array}{l}\text { Without fertilisation PK } \\
\text { Series I }\end{array}$} & 1 & 6.18 & 6.15 \\
\hline & 2 & 6.20 & 6.17 \\
\hline & 3 & 6.30 & 6.20 \\
\hline & 4 & 6.32 & 6.28 \\
\hline & 5 & 6.38 & 6.34 \\
\hline & mean & $x$ & $x$ \\
\hline \multirow{6}{*}{$\begin{array}{l}\text { With additional PK fertilisation } \\
\text { Series II }\end{array}$} & 6 & 6.17 & 6.14 \\
\hline & 7 & 6.19 & 6.18 \\
\hline & 8 & 6.28 & 6.26 \\
\hline & 9 & 6.33 & 6.36 \\
\hline & 10 & 6.42 & 6.46 \\
\hline & mean & $\mathbf{x}$ & $x$ \\
\hline \multicolumn{2}{|l|}{$\begin{array}{l}\text { LSD } \\
\text { I-dos for: } \\
\text { I-dose PRP Fix } \\
\text { Il- with and without of PK } \\
\text { interaction }\end{array}$} & $\begin{array}{l}0.06 \\
0.04 \\
0.06\end{array}$ & $\begin{array}{l}0.06 \\
0.08 \\
0.07\end{array}$ \\
\hline
\end{tabular}

* Explanation of fertilisation objects - experimental series I: 1 - mineral fertilisers corresponding to a slurry dose, 2 - slurry without PRP Fix, 3 - slurry +4 kg PRP Fix, $4-$ slurry +8 kg PRP Fix, $5-$ slurry +12 kg PRP Fix; experimental series II: 6 - mineral fertilisers corresponding to a slurry dose with additional PK fertilisation, 7 - slurry without PRP Fix + PK, 8 - slurry +4 kg PRP Fix + PK, $9-$ slurry +8 kg PRP Fix + PK, $10-$ slurry + $12 \mathrm{~kg}$ PRP Fix + PK. 
nitrogen content in soil after test plants harvest was recorded between object 1 (exclusively mineral fertilization) and 10 (slurry $+12 \mathrm{~kg}$ PRP FIX $+\mathrm{PK})$, respectively by $16.7 \%$ and $21.3 \%$. The results indicate that the applied PK nutrition along with PRP FIX in series II contributed to the nitrogen amount increase in the soil after test plants harvest by $4.25 \%$ and $3.10 \%$, respectively. The increase in nitrogen concentration between series I and II was negligible. The applied fertilization systems had no influence on the increase or decrease in nitrogen content in the soil.

The PRP FIX preparation added into the slurry at the amount of $8 \mathrm{~kg}$ per $1 \mathrm{~m}^{3}$ both in the series with and without additional PK nutrition (series I and II) contributed to the increase in the organic carbon concentration in soil after wheat and potato harvest (Table 4). The largest increase in this parameter was recorded between object 1 (mineral fertilization only) and 10 (slurry $+12 \mathrm{~kg}$ PRP FIX + PK) by $23.6 \%$ and $11.5 \%$, respectively. The results indicate that the applied PK nutrition along with PRP FIX in series II affected the increase in organic carbon content in the soil after wheat harvest by $4.46 \%$ as compared to the series I. Average organic carbon content increase between series I and II was low and oscillated from 0.8 to $4.46 \%$. The applied fertilization systems did not influence the increase or decrease in organic carbon concentration in the soil. The use of slurry caused the increase in nitrogen and organic carbon contents in the studied soil. Similar results have been reported by Mazur and Sądej [1989], Sieradzki [2006].

The largest increase in phosphorus concentration was achieved in the soil after wheat and potato harvest between fertilization objects 1 and 10 , respectively by $20.4 \%$ and $18.1 \%$ (Table 5 ). When comparing both study series, it was found that additional PK nutrition along with PRP FIX contributed to the phosphorus content increase in soil after test plants harvest, respectively by $7.50 \%$ and $8.58 \%$. Average increase in phosphorus concentration in soil amounted to $7.10 \%$ and $9.67 \%$ in relation to the values before experiment establishment. The results indicate that objects with slurry along with PRP FIX in series I and II (fertilization objects 3, 4, 5, 8, 9, and 10) revealed an increase in potassium content in the soil after experiment completion as referenced to object 1 , in which mineral fertilizers were applied at rates corresponding to the slurry dose used (Table 5). The slurry introduced along with PRP FIX at the amount of $12 \mathrm{~kg} \mathrm{per} \mathrm{m}^{3}$ in series with and without complementary PK nutrition (series II) resulted in the largest increase in potassium content in the soil as compared to the initial value, respectively by $9.62 \%$ and $10.0 \%$. The increase in this element concentration in the soil between objects 1 and 10 amounted respectively to $8.82 \%$ and $8.39 \%$. The applied slurry and PK mineral fertilizers treatment contributed to the increase in phosphorus and po-

Table 4. Effect of slurry and PRP Fix on nitrogen content, organic carbon and C:N ratio in soil after harvest of test plants

\begin{tabular}{|c|c|c|c|c|c|c|c|}
\hline \multirow{3}{*}{$\begin{array}{l}\text { Exsperiment } \\
\text { series }\end{array}$} & \multirow{3}{*}{$\begin{array}{c}\text { Fertilisation } \\
\text { objects }\end{array}$} & \multicolumn{2}{|c|}{$\mathrm{N}$} & \multicolumn{2}{|c|}{ C org. } & \multicolumn{2}{|c|}{$\mathrm{C}: \mathrm{N}$} \\
\hline & & \multicolumn{6}{|c|}{ total content in $\mathrm{g} \cdot \mathrm{kg}^{-1} \mathrm{~d} . \mathrm{m}$. } \\
\hline & & wheat & potato & wheat & potato & wheat & potato \\
\hline \multicolumn{2}{|l|}{ The output value } & \multicolumn{2}{|c|}{0.86} & \multicolumn{2}{|c|}{8.80} & \multicolumn{2}{|c|}{10.2} \\
\hline \multirow{6}{*}{$\begin{array}{l}\text { Without fertilisation } \\
\text { PK } \\
\text { Series I }\end{array}$} & 1 & 0.90 & 0.89 & 8.90 & 8.87 & 9.89 & 9.97 \\
\hline & 2 & 0.95 & 0.91 & 9.12 & 8.98 & 9.60 & 9.87 \\
\hline & 3 & 0.98 & 0.95 & 9.36 & 9.28 & 9.55 & 9.77 \\
\hline & 4 & 0.94 & 0.98 & 9.49 & 9.49 & 10.1 & 9.68 \\
\hline & 5 & 0.96 & 1.02 & 10.2 & 10.1 & 10.6 & 9.90 \\
\hline & mean & 0.94 & 0.95 & 9.41 & 9.34 & 10.0 & 9.83 \\
\hline \multirow{6}{*}{$\begin{array}{l}\text { With additional PK } \\
\text { fertilisation } \\
\text { Series II }\end{array}$} & 6 & 0.92 & 0.91 & 8.96 & 8.98 & 9.73 & 9.87 \\
\hline & 7 & 0.93 & 0.93 & 9.05 & 9.12 & 9.74 & 9.81 \\
\hline & 8 & 0.98 & 0.95 & 9.55 & 9.45 & 9.75 & 9.95 \\
\hline & 9 & 1.02 & 1.02 & 10.6 & 9.62 & 10.4 & 9.44 \\
\hline & 10 & 1.05 & 1.08 & 11.0 & 9.89 & 10.5 & 9.16 \\
\hline & mean & 0.98 & 0.98 & 9.83 & 9.41 & 10.3 & 9.60 \\
\hline \multicolumn{2}{|c|}{$\begin{array}{l}\text { LSD }_{0.05} \text { for: } \\
\text { I-dose PRP Fix } \\
\text { Il- with and without of PK } \\
\text { interaction }\end{array}$} & $\begin{array}{l}0.06 \\
0.05 \\
\text { n.s. }\end{array}$ & $\begin{array}{l}\text { n.s. } \\
0.07 \\
\text { n.s. }\end{array}$ & $\begin{array}{l}0.10 \\
0.21 \\
0.19\end{array}$ & $\begin{array}{l}0.10 \\
0.21 \\
0.19\end{array}$ & $\begin{array}{l}0.06 \\
0.11 \\
0.10\end{array}$ & $\begin{array}{l}0.15 \\
0.07 \\
0.19\end{array}$ \\
\hline
\end{tabular}

*Explanation of fertilisation objects is given under Table 3 
Table 5. Effect of slurry and PRP Fix on the content of phosphorus, potassium and magnesium in soil after harvest of test plants

\begin{tabular}{|c|c|c|c|c|c|c|c|}
\hline \multirow{3}{*}{$\begin{array}{l}\text { Exsperiment } \\
\text { series }\end{array}$} & \multirow{3}{*}{ Fertilisation objects } & \multicolumn{2}{|c|}{$\mathrm{P}$} & \multicolumn{2}{|c|}{$\mathrm{K}$} & \multicolumn{2}{|c|}{$\mathrm{Mg}$} \\
\hline & & \multicolumn{6}{|c|}{ total content in $\mathrm{g} \cdot \mathrm{kg}^{-1} \mathrm{~d} . \mathrm{m}$. } \\
\hline & & wheat & potato & wheat & potato & wheat & potato \\
\hline \multicolumn{2}{|l|}{ The output value } & \multicolumn{2}{|c|}{1.55} & \multicolumn{2}{|c|}{2.70} & \multicolumn{2}{|c|}{0.65} \\
\hline \multirow{4}{*}{$\begin{array}{l}\text { Without } \\
\text { fertilisation PK }\end{array}$} & 1 & 1.57 & 1.60 & 2.72 & 2.74 & 0.68 & 0.68 \\
\hline & 2 & 1.59 & 1.62 & 2.75 & 2.78 & 0.71 & 0.71 \\
\hline & 3 & 1.62 & 1.65 & 2.80 & 2.86 & 0.75 & 0.86 \\
\hline & 4 & 1.60 & 1.62 & 2.92 & 2.92 & 0.83 & 0.85 \\
\hline \multirow[t]{2}{*}{ Series I } & 5 & 1.66 & 1.66 & 2.96 & 2.98 & 0.80 & 0.86 \\
\hline & mean & 1.60 & 1.63 & 2.83 & 2.85 & 0.75 & 0.79 \\
\hline \multirow{6}{*}{$\begin{array}{l}\text { With additional PK } \\
\text { fertilisation }\end{array}$} & 6 & 1.58 & 1.65 & 2.74 & 2.73 & 0.71 & 0.72 \\
\hline & 7 & 1.61 & 1.68 & 2.78 & 2.75 & 0.72 & 0.74 \\
\hline & 8 & 1.75 & 1.80 & 2.82 & 2.82 & 0.85 & 0.83 \\
\hline & 9 & 1.81 & 1.86 & 2.88 & 2.89 & 0.88 & 0.85 \\
\hline & 10 & 1.89 & 1.89 & 2.96 & 2.97 & 0.92 & 0.86 \\
\hline & mean & 1.72 & 1.77 & 2.84 & 2.83 & 0.82 & 0.80 \\
\hline \multicolumn{2}{|c|}{$\begin{array}{l}\text { LSD }{ }_{0.05} \text { for: } \\
\text { I-dose PRP Fix } \\
\text { II- with and without of PK } \\
\text { interaction }\end{array}$} & $\begin{array}{l}0.03 \\
0.08 \\
0.06\end{array}$ & $\begin{array}{l}0.06 \\
0.10 \\
0.09\end{array}$ & $\begin{array}{l}\text { n.s. } \\
0.11 \\
\text { n.s. }\end{array}$ & $\begin{array}{l}\text { n.s. } \\
0.09 \\
\text { n.s. }\end{array}$ & $\begin{array}{l}\text { n.s. } \\
\text { n.s. } \\
0.04\end{array}$ & $\begin{array}{l}\text { n.s. } \\
0.06 \\
\text { n.s. }\end{array}$ \\
\hline
\end{tabular}

* Explanation of fertilisation objects is given under Table 3

tassium levels in the soil after test plants harvest, which was confirmed in studies performed by Kwaśny [2011], Mazur and Maćkowiak [1978].

The largest magnesium increase was observed in the soil after wheat harvest $\left(0.92 \mathrm{~g} \cdot \mathrm{kg}^{-}\right.$ ${ }^{1}$ d.m.) and in object 10 , while after potato harvest - in objects 3,5 , and 10 at the quantity of $0.86 \mathrm{~g} \cdot \mathrm{kg}^{-1} \mathrm{~d}$.m. (Table 5). When comparing the series I with II, it is obvious that complementary PK nutrition along with PRP FIX resulted in an increase in magnesium content in soil both after wheat and potato tubers harvest, respectively by $24.4 \%$ and $17.6 \%$ as compared to object 6 . The increase in magnesium concentration after test plants harvest was achieved in series I and II by $15.4 \%$ and $26.1 \%$ in relation to levels before the experiment had begun. Likewise phosphorus and potassium, the largest magnesium concentration increase in the soil after experiment completion was recorded in objects with slurry and PRP FIX at quantities of 8 and $12 \mathrm{~kg}$ per $\mathrm{m}^{3}$ in both series of study (objects 4, 5, 9, and 10), while the smallest in object 1 (Table 5).

The analysis of the achieved results referring to fertilization objects with slurry along with PRP FIX applied in both series (objects 3, 4, 5, 8, 9, and 10) has shown that calcium concentration increased in the soil after test plants harvest, as compared to object 1 (Table 6). The slurry used with PRP FIX at the amount of $12 \mathrm{~kg}^{\mathrm{ger}} \mathrm{m}^{3}$ in series without and with complementary PK nutri- tion caused the increase in calcium level in soils in all fertilization objects where potato was grown, comparing with objects 1 and 6 as well as values before experiment setting, respectively by $13.0 \%$, $14.7 \%$, and $15.9 \%$. The results indicate that there was an increase in the content of calcium in soil between both study series after test plants harvest.

The study results achieved in the fertilization objects where slurry along with PRP FIX was used in series I and II indicate the increase in sulfur content in the soil after wheat and potato harvest, respectively by $7.69 \%$ and $16.0 \%$ as compared to object 1 (Table 6). The applied slurry with PRP FIX preparation at the doses of 8 and $12 \mathrm{~kg}$ per $\mathrm{m}^{3}$ in series with and without additional PK nutrition (series I and II) caused an increase in sulfur concentration in the soil of objects 4 , 5,9 , and 10. The largest increase in the element level was recorded in the soil after potato harvest, which amounted to $0.41 \mathrm{~g} \cdot \mathrm{kg}^{-1} \mathrm{~d}$.m. (object 10 ). Sulfur concentration in soil was higher by $13.9 \%$ in reference to the object with PRP FIX applied at the rate of $8 \mathrm{~kg}$ per $1 \mathrm{~m}^{3}$ of slurry, and when compared to the level before experiment setting - by $64 \%$. A moderate increase in sulfur content referred to series I and II in the soil was $14 \%$ and $26 \%$, respectively.

Significantly less plant-available forms of phosphorus, potassium, magnesium, and sulfate in the soil were determined in the following fertilization objects: without fertilization, with PK 
Table 6. Effect of slurry formulation and PRP Fix for calcium and sulfur in the soil after harvest of the test plants

\begin{tabular}{|c|c|c|c|c|c|}
\hline \multirow{3}{*}{ Exsperiment series } & \multirow{3}{*}{$\begin{array}{c}\text { Fertilisation } \\
\text { objects }\end{array}$} & \multicolumn{2}{|c|}{$\mathrm{Ca}$} & \multicolumn{2}{|c|}{$S$} \\
\hline & & \multicolumn{4}{|c|}{ total content in $\mathrm{g} \cdot \mathrm{kg}^{-1} \mathrm{~d} . \mathrm{m}$. } \\
\hline & & wheat & potato & wheat & potato \\
\hline \multicolumn{2}{|l|}{ The output value } & \multicolumn{2}{|c|}{1.95} & \multicolumn{2}{|c|}{0.25} \\
\hline \multirow{6}{*}{$\begin{array}{l}\text { Without fertilisation } \\
\text { PK } \\
\text { Series I }\end{array}$} & 1 & 1.99 & 2.00 & 0.26 & 0.27 \\
\hline & 2 & 2.01 & 2.03 & 0.27 & 0.28 \\
\hline & 3 & 2.10 & 2.20 & 0.27 & 0.31 \\
\hline & 4 & 2.16 & 2.25 & 0.28 & 0.35 \\
\hline & 5 & 2.27 & 2.21 & 0.29 & 0.34 \\
\hline & mean & 2.10 & 2.14 & 0.27 & 0.31 \\
\hline \multirow{6}{*}{$\begin{array}{l}\text { With additional PK } \\
\text { fertilisation } \\
\text { Series II }\end{array}$} & 6 & 1.98 & 1.97 & 0.25 & 0.24 \\
\hline & 7 & 2.05 & 2.01 & 0.26 & 0.27 \\
\hline & 8 & 2.10 & 2.08 & 0.28 & 0.32 \\
\hline & 9 & 2.16 & 2.21 & 0.29 & 0.36 \\
\hline & 10 & 2.20 & 2.26 & 0.30 & 0.41 \\
\hline & mean & 2.10 & 2.10 & 0.30 & 0.32 \\
\hline \multicolumn{2}{|c|}{$\begin{array}{l}\text { LSD } \\
\text { I-dose } \text { for: } \\
\text { II- with and Fix } \\
\text { interaction }\end{array}$} & $\begin{array}{l}\text { n.s. } \\
0.09 \\
\text { n.s. }\end{array}$ & $\begin{array}{l}0.04 \\
0.08 \\
\text { n.s. }\end{array}$ & $\begin{array}{l}\text { n.s. } \\
\text { n.s. } \\
\text { n.s. }\end{array}$ & $\begin{array}{l}\text { n.s. } \\
0.02 \\
0.03\end{array}$ \\
\hline
\end{tabular}

*Explanation of fertilisation objects is given under Table 3

nutrition, and with slurry yet without PRP FIX addition (Table 7, 8). Referring both to series with and without complementary PK fertilization, the largest amounts of available forms of phosphorus, potassium, magnesium, and sulfates were found in the soil from objects where slurry was applied along with 8 and $12 \mathrm{~kg}$ per $\mathrm{m}^{3}$ of PRP FIX preparation. However, differences in these parameters between the above objects were not always significant. In series II with additional mineral PK nutrition, the content of plant-available macronutrients forms in the soil after test plants harvest, in general it increased as compared to series I, that was used without complementary PK fertilization. Evaluation of average contents of available components in the soil applied by ChemicalAgricultural Stations by means of the number of border, it was recorded that phosphorus and potassium concentrations were at moderate levels in fertilization objects in series I and II, which indicates that no change in the soil abundance class was observed. Meanwhile, available magnesium content in the soil indicated its average abundance class. Considering the available magnesium form content, the soil class has changed from average to high due to the fertilization applied.

Taking into account the study results achieved by Krzywy [2005] and Maćkowiak [2000]_characterizing some soil properties depending on macronutrients contents, it can be concluded that fertilization using slurry and PK mineral fertilizers with increasing doses of PRP FIX preparation did not adversely affect the natural environment.

\section{CONCLUSIONS}

1. The largest quantities of organic carbon, total nitrogen, phosphorus, potassium, magnesium, calcium, and plant-available forms of phosphorus, potassium, magnesium, and sulfates were found in the soil from objects where slurry was combined with 8 or $12 \mathrm{~kg}$ per $1 \mathrm{~m}^{3}$ of PRP FIX preparation.

2. Additional PK nutrition (series II) caused the increase in organic carbon as well as total nitrogen, phosphorus, and potassium contents in soil, not having any significant impact on the differentiation in magnesium, calcium, and sulfur, as well as plant-available forms of phosphorus, potassium, magnesium, and sulfates.

3. Addition of PRP FIX into the slurry optimally improved the soil fertility indicators. From a practical point of view, as well as taking costs into account, a dose of $8 \mathrm{~kg}$ of PRP FIX preparation should be added to $1 \mathrm{~m}^{3}$ of slurry.

4. Fertilization applied in series I and II contributed to the change the soil quality class from moderately to highly abundant in available magnesium.

5. The study results indicate the possibility of applying the slurry in combination with PRP FIX and additional PK nutrition for soils and plants fertilization with no risk of their negative effects on crop yields and environmental pollution. 
Table 7. Effect of slurry and PRP Fix on the content of assimilable forms of phosphorus and potassium in soil after harvest of test plants

\begin{tabular}{|c|c|c|c|c|c|}
\hline \multirow{3}{*}{ Exsperiment series } & \multirow{3}{*}{$\begin{array}{c}\text { Fertilisation } \\
\text { objects }\end{array}$} & \multicolumn{2}{|c|}{$\mathrm{P}$} & \multicolumn{2}{|c|}{$\mathrm{K}$} \\
\hline & & \multicolumn{4}{|c|}{ forms of available content in $\mathrm{g} \cdot \mathrm{kg}^{-1} \mathrm{~d} . \mathrm{m}$. } \\
\hline & & wheat & potato & wheat & potato \\
\hline \multicolumn{2}{|l|}{ The output value } & \multicolumn{2}{|c|}{55.3} & \multicolumn{2}{|c|}{132.0} \\
\hline \multirow{6}{*}{$\begin{array}{l}\text { Without fertilisation } \\
\text { PK } \\
\text { Series I }\end{array}$} & 1 & 57.0 & 55.9 & 134 & 134 \\
\hline & 2 & 56.0 & 56.1 & 133 & 132 \\
\hline & 3 & 59.1 & 57.9 & 138 & 135 \\
\hline & 4 & 59.7 & 58.7 & 141 & 137 \\
\hline & 5 & 60.3 & 59.3 & 144 & 141 \\
\hline & mean & 58.5 & 57.6 & 138 & 135.8 \\
\hline \multirow{6}{*}{$\begin{array}{l}\text { With additional PK } \\
\text { fertilisation } \\
\text { Series II }\end{array}$} & 6 & 56.9 & 56.1 & 134 & 133 \\
\hline & 7 & 55.6 & 56.0 & 133 & 133 \\
\hline & 8 & 58.2 & 58.2 & 137 & 136 \\
\hline & 9 & 59.6 & 59.7 & 140 & 139 \\
\hline & 10 & 61.9 & 61.1 & 142 & 140 \\
\hline & mean & 58.5 & 58.2 & 137 & 136.2 \\
\hline \multicolumn{2}{|c|}{$\begin{array}{l}\text { LSD }{ }_{0.05} \text { for: } \\
\text { I-dose PRP Fix } \\
\text { II- with and without of PK } \\
\text { interaction }\end{array}$} & $\begin{array}{l}0.24 \\
0.56 \\
0.53\end{array}$ & $\begin{array}{l}0.36 \\
0.85 \\
\text { n.s. }\end{array}$ & $\begin{array}{l}\text { n.s. } \\
4.16 \\
\text { n.s. }\end{array}$ & $\begin{array}{l}\text { n.s. } \\
1.58 \\
\text { n.s. }\end{array}$ \\
\hline
\end{tabular}

*Explanation of fertilisation objects is given under Table 3

Table 8. Effect of slurry and PRP Fix on the content of assimilable forms of magnesium and sulphate sulfur in soil after harvest of test plants

\begin{tabular}{|c|c|c|c|c|c|}
\hline \multirow{3}{*}{ Exsperiment series } & \multirow{3}{*}{$\begin{array}{l}\text { Fertilisation } \\
\text { objects }\end{array}$} & \multicolumn{2}{|c|}{$\mathrm{Mg}$} & \multicolumn{2}{|c|}{$\mathrm{SO}_{3}$} \\
\hline & & \multicolumn{4}{|c|}{ forms of available content in $\mathrm{g} \cdot \mathrm{kg}^{-1} \mathrm{~d} . \mathrm{m}$. } \\
\hline & & wheat & potato & wheat & potato \\
\hline \multicolumn{2}{|l|}{ The output value } & \multicolumn{2}{|c|}{49.3} & \multicolumn{2}{|c|}{11.0} \\
\hline \multirow{6}{*}{$\begin{array}{l}\text { Without fertilisation PK } \\
\text { Series I }\end{array}$} & 1 & 57.9 & 57.6 & 11.1 & 11.2 \\
\hline & 2 & 57.6 & 57.2 & 11.2 & 11.3 \\
\hline & 3 & 58.6 & 59.4 & 11.5 & 11.6 \\
\hline & 4 & 60.6 & 62.1 & 11.6 & 11.8 \\
\hline & 5 & 62.8 & 63.2 & 11.7 & 12.0 \\
\hline & mean & 59.5 & 59.9 & 11.4 & 11.6 \\
\hline \multirow{6}{*}{$\begin{array}{l}\text { With additional PK } \\
\text { fertilisation } \\
\text { Series II }\end{array}$} & 6 & 58.5 & 58.0 & 11.2 & 11.1 \\
\hline & 7 & 57.0 & 57.6 & 11.3 & 11.3 \\
\hline & 8 & 61.3 & 59.6 & 11.5 & 11.6 \\
\hline & 9 & 62.6 & 61.8 & 11.7 & 11.9 \\
\hline & 10 & 63.8 & 63.1 & 11.8 & 12.1 \\
\hline & mean & 60.8 & 60.0 & 11.5 & 11.6 \\
\hline \multicolumn{2}{|l|}{$\begin{array}{l}\text { LSD }_{0.05} \text { for: } \\
\text { I-dose PRP Fix } \\
\text { II- with and without of PK } \\
\text { interaction }\end{array}$} & $\begin{array}{l}0.19 \\
0.44 \\
0.42\end{array}$ & $\begin{array}{l}\text { n.s. } \\
0.48 \\
\text { n.s. }\end{array}$ & $\begin{array}{l}\text { n.s. } \\
\text { n.s. } \\
\text { n.s. }\end{array}$ & $\begin{array}{l}\text { n.s. } \\
0.22 \\
\text { n.s. }\end{array}$ \\
\hline
\end{tabular}

*Explanation of fertilisation objects is given under Table 3

\section{Acknowledgements}

The study performed within the project of NCN no N N 304056140.

\section{REFERENCES}

1. Blanes-Vidal V., Hansen M.N., Pedersen S., Rom H.B., 2008. Emissions of ammonia, methane and nitrous oxide from pig houses and slurry. Effects of rooting material, animal activity and ventilation flow. Agriculture, Ecosystems and Environment. 124, 237-244.

2. Dobrzański Z., Górecki H., Hoffman J., Kołacz R., Chojnacki A., 2004. Problems of disposal of slaughterhouse waste and animal meal.VI Konferencja Technologie bezodpadowe i zagospodarowanie odpadów w przemyśle i rolnictwie. Politechnika Szczecińska. Międzyzdroje. 109-111. [in Polish] 
3. Filipek T., 2006. Agricultural chemistry. Theoretical and analytical basics Wyd. AR Lublin.12-34. [In Polish]

4. Gianfreda L., Ruggiero P., Nannipieri W. P., Smalla K., 2006. Soil biology. Enzyme activities in soil. Nucleic acids and proteins in soil. Springer-Verlang, 8,257-311.

5. Gorlach E., Mazur T., 2001. Agricultural chemistry. Wyd. Nauk PWN, Warszawa, 55-74. [In Polish]

6. Hoffmann J., Gryglewicz G., Hoffmann K., Gryglewicz S., Rutkowski P., 2010. Influence of technological modifications of fertilizers on the emission of odorous compounds. Przemysł Chemiczny. 89(4), 386-390. [In Polish]

7. Krzywy E., 2005. About slurry once again. Aura, Wyd. Sigma 4,16-17. [In Polish]

8. Mazur T., Maćkowiak M., 1978. Fertilization with slurry. Wyd. PWRiL [In Polish]

9. Mazur T., Sądej W., 1989. Effect of long-term fertilization with slurry, manure and NPK on some chemical and physicochemical properties of soil. Rocz. Gleb. 40(1), 147-153. [In Polish]

10. Maćkowiak Cz. 2000. Slurry properties and rules for applying with the environment. Mater. Szkol. Puławy IUNG 75, 1-30. [In Polish]

11. Nortcliff S., 2002. Standarisation of soil quality attributes. Agric. Ekosys. Environ., 88,161-168.
12. Renella G., Landi L., Valori F., Nannipieri P., 2007. Microbial and hdrolase activity after relase of low molecular weght organic compounds by a model root surface in a clayey and a sand soil. Appl. Soil Ecol., 36, 124-129.

13. Kwaśny J., Kowalski B., Banach Z., 2011. Slurry properties of slurry in the context of content of selected macro and microelements. Czasopismo Techniczne, Chemia 108(2),107-120. [In Polish]

14. Sieradzki T., 2006. Effect of long-term fertilization of arable land with slurry and mineral fertilizers on nitrogen and phosphorus content in groundwater. Problemy Inżynierii Rolniczej 14(2),45-52. [In Polish]

15. Trasar-Cepeda, M.C. Leiros, F. Gil-Sotres, 2008. Hydrolytic enzyme activities in agricultural and forest soils. Some implications for their use a indicators of soil quality. Soil Biol. Biochem 40, 2146-2155.

16. Yang L., Li T., Li F., Lemcoff J.H., Cohen S., 2008. Fertilization regulates soil enzymatic activity and ferility dynamics in cucumber field. Scientia Horticul, 116, 21-26.

17. Zhao Y., Wang P., Chen J. Li, Y., Ying X., Liu S., 2009. The effect of two organic manures on soil properties and crop yields on a temperate calcareous soil under a wheat-maize cropping system. Europ. J. Agron. 31(1),36-42. 